\title{
Women Vision of Higher Education Opportunities in Kazakhstan
}

\author{
Aigerim Yessentay ${ }^{1}$, Gaukhar K. Kenzhegulova ${ }^{2 *}$, Osama M. Rajkhan ${ }^{3}$ \\ ${ }^{1}$ Institute of Economics of the Science Committee of the Ministry of Education \\ and Science of the Republic of Kazakhstan, 29 Kurmangazy str., 050010, Almaty, Kazakhstan, \\ ${ }^{2} N A R X O Z$ University, 55 Zhandosova str., 050035, Almaty, Kazakhstan, \\ ${ }^{3}$ American University of Sovereign Nations, Saudi Arabia
}

\begin{abstract}
Education has become an important mechanism in the goal of gender equality achievement. For many decades, access to education was one of the key issues for women. These days it is an issue of not only developing countries but of developed ones as well. Women have become more active in higher education, especially in achieving master degree or $\mathrm{PhD}$. This is due to that public policies are directed at the improvement of the structure of higher education. It includes promotion of human resources diversification among academic staff. This article studies the vision of women regarding higher education. What is the importance of it? This is especially carrier opportunities in higher education. It also discusses carrier opportunities for women in other fields, which has influence on women desire to continue their education. What influence does it have on private life? Higher education also covers state of selfdevelopment, personal improvement and family relationships. The study was provided under the framework of social behavior communication change, which includes four key factors of social behavior. There was conducted a semistructured interview among women. For the interview analysis, Dedoose software was used. According to the results of the study, there have been identified two main factors, which have a great Impact on women participation in higher education. These factors are cultural standard family issues. Major outcomes of higher education for women: potential realization, promotion of women rights. This determines the importance of social behavior in the development of a policy, development of laws and regulations.
\end{abstract}

Key words: higher education, gender equality, cultural standards, empowerment, carrier.

For citation: Yessentay, A., Kenzhegulova, G.K. \& Rajkhan, O.M. (2021). Women Vision of Higher Education Opportunities in Kazakhstan. Economics: the Strategy and Practice, 16(3), 204-216, https://doi.org/10.51176/1997$\underline{9967-2021-3-204-216}$

* Corresponding author: Gaukhar K. Kenzhegulova - PhD student, NARXOZ University, 050035, Almaty, st. Zhandosova 55, Kazakhstan, +87014522521, e-mail: gaukhar.kenzhegulova@gmail.com

Conflict of interests: the authors declare that there is no conflict of interest

Financial support: This research has been supported by the Ministry of Education and Science of the Republic of Kazakhstan within the project «The science impact on Kazakhstan's socio-economic development: methodology, assessment models and development scenarios» (IRN AP08052745).

The article received: 31.05 .2021

The article approved for publication: 16.06 .2021

Date of publication: 30.09 .2021 


\title{
Қазақстандағы әйелдердің жоғары білім алу мүмкіндіктері
}

\author{
Есентай А.Е. ${ }^{1}$, Кенжегулова Г.К. ${ }^{2 *}$, Осама М. Раджхан ${ }^{3}$ \\ ${ }^{1}$ Қазақсттан Республикасы Білім және вылым министрлігі Ғылым комитетінің \\ Экономика институты, Құрмангазы к., 29, 050010, Алматы қ., Қазақ̆стан, \\ ${ }^{2}$ НАРХОЗ университеті, Жандосов көшесі, 55, 050035, Алматы, Қазақсстан, \\ ${ }^{3}$ Американдық Егеменді Ұлттар Университеті, Сауд Арабиясы
}

\begin{abstract}
Түйін
Білім гендерлік теңдікке жетудегі маңызды механизмге айналды. Көптеген ондаған жылдар бойы білімге қол жеткізу әйелдер үшін басты мәселелердің бірі болды. Бұл мәселе тек дамушы елдердің ғана емес, дамыған елдердің де мәселесі. Әйелдер жоғары оку орындарында, әсіресе магистратура немесе $\mathrm{PhD}$ докторантураға түсуде белсенділік таныта бастады. Бұл мемлекеттік саясаттың жоғары білім құрылымын жетілдіруге бағытталғандығымен байланысты. Ол ғылыми қызметкерлер арасында адам ресурстарын әртараптандыруды насихаттауды қамтиды. Бұл мақалада әйелдердің жоғары білімге деген көзқарасы зерттеледі. Оның маңыздылығы неде? Бұл, әсіресе, жоғары оқу орындарының мүмкіндіктері. Ол сонымен қатар әйелдердің білімін жалғастыруға деген ықыласына әсер ететін басқа саладағы әйелдердің тасымалдау мүмкіндіктерін талқылайды. Оның жеке өмірге әсері қандай? Жоғары білім сонымен қатар өзін-өзі дамыту, жеке жетілу және отбасылық қарым-қатынасты қамтиды. Зерттеу әлеуметтік мінез -құлықтың төрт негізгі факторын қамтитын әлеуметтік мінез -құлық қарым -қатынасының өзгеруі аясында ұсынылды. Әйелдер арасында жартылай құрылымдық сұхбат жүргізілді. Сұхбатты талдау үшін Dedoose бағдарламалық жасақтамасы қолданылды. Зерттеу нәтижелері бойынша әйелдердің жоғары оқу орындарына қатысуына үлкен әсер ететін екі негізгі фактор анықталды. Бұл факторлар мәдени стандартты отбасылық мәселелер. Әйелдерге жоғары білім берудің негізгі нәтижелері: әлеуетті іске асыру, әйелдер құқығын қолдау. Бұл әлеуметтік мінез -құлықтың саясатты әзірлеудегі, заңдар мен нормативтік құқықтық актілердегі маңыздылығын анықтайды.
\end{abstract}

Түйін сөздер: жоғары білім, гендерлік теңдік, мәдени стандарттар, мүмкіндіктер, тасымалдаушы

Дәйексөз алу үшін: Есентай А., Кенжегулова Г.К., Осама М. Раджхан (2021). Қазақстандағы әйелдердің жоғары білім алу мүмкіндіктері. Экономика: стратегия және практика, 16(3), 204-216, https://doi. org/10.51176/1997-9967-2021-3-204-216

* Хат-хабаршы авторы: Кенжегулова Гаухар Коблановна - докторант, НАРХОЗ университеті, 050035, Алматы қ., Жандосова к. 55, Қазақстан, +8701452252, e-mail: gaukhar.kenzhegulova@gmail.com.

Мүдделер қақтығысы: авторлар мүдделер қақтығысының жоқтығын мәлімдейді.

Қаржыландыру. Мақала ҚР Білім және ғылым министрлігінің «Қазақстанның әлеуметтік-экономикалық дамуына ғылымның әсері: әдістеме, бағалау модельдері және даму сценарийлері» (IRN AR08052745) гранттық қаржыландыру жобасы аясында дайындалған.

Мақала редакцияға түсті: 31.05 .2021

Жариялау туралы шешім қабылданды: 16.06 .2021

Жарияланды: 30.09 .2021 


\title{
Женский взгляд на возможности получения высшего образовании в Казахстане
}

\author{
Есентай А.Е. ${ }^{1}$, Кенжегулова Г.К. ${ }^{*}$, Осама М. Раджхан ${ }^{3}$ \\ ${ }^{1}$ Институт экономики Комитета науки Министерства образования и науки Республики \\ Казахстан, ул. Курмангазы,29, 050010, г. Алматы, Казахстан, \\ ${ }^{2}$ Университет НАРХОЗ, ул. Жандосова 55, 050035, г.Алматы, Казахстан, \\ ${ }^{3}$ Американский Университет Суверенных Наџий, Саудовская Аравия
}

\begin{abstract}
Аннотация
Образование стало важным механизмом в достижении гендерного равенства. На протяжении многих десятилетий доступ к образованию был одним из ключевых вопросов для женщин. Сегодня это проблема не только развивающихся, но и развитых стран. Женщины стали более активными в сфере высшего образования, особенно в получении степени магистра или доктора философии. Это связано с тем, что государственная политика направлена на улучшение структуры высшего образования. Он включает содействие диверсификации человеческих ресурсов среди академического персонала. В данной статье исследуется видение женщин относительно высшего образования. В чем важность этого? Это особенно карьерные возможности в высшем образовании. В нем также обсуждаются возможности карьерного роста для женщин в других областях, что влияет на желание женщин продолжить свое образование. Какое влияние это оказывает на личную жизнь? Высшее образование также охватывает состояние саморазвития, личного совершенствования и семейных отношений. Исследование проводилось в рамках изучения коммуникативного изменения социального поведения, которое включает четыре ключевых фактора социального поведения. Среди женщин было проведено полуструктурированное интервью. Для анализа интервью использовалась программа Dedoose. По результатам исследования были выявлены два основных фактора, которые имеют большое влияние на участие женщин в высшем образовании. Эти факторы являются культурными стандартными семейными проблемами. Основные результаты высшего образования для женщин: реализация потенциала, продвижение прав женщин. Это определяет важность социального поведения при разработке политики, разработке законов и нормативных актов.
\end{abstract}

Ключевые слова: высшее образование, гендерное равенство, культурные стандарты, расширение прав и возможностей, карьера.

Для цитирования: Есентай А.Е., Кенжегулова Г.К., Раджхан О.М. (2021). Женский взгляд на возможности получения высшего образования в Казахстане. Экономика: стратегия и практика, 16(3), 204-216, https://doi. org/10.51176/1997-9967-2021-3-204-216

* Корреспондирующий автор: Кенжегулова Гаухар Коблановна - докторант, Университет НАРХОЗ, 050035, г.Алматы, ул. Жандосова 55, Казахстан, +87014522521, e-mail: gaukhar.kenzhegulova@gmail.com.

Конфликт интересов: авторы заявляют об отсутствии конфликта интересов.

Финансирование. Статья подготовлена в рамках проекта грантового финансирования Министерства образования и науки Республики Казахстан «Влияние науки на социально-экономическое развитие Казахстана: методология, модели оценки и сценарии развития» (ИРН АР08052745).

Статья поступила в редакцию: 31.05 .2021

Принято решение о публикации: 16.06 .2021

Опубликовано: 30.09 .2021 


\section{Introduction}

Society has been dealing with the rapid development of countries in different directions. If unemployment earlier would be reflecting in the number of job seekers, these days this is rather different. The unemployment of these days is measured by self-employment or development of small and medium businesses. In addition, this list includes the description of a curriculum vita (CV) of a candidate or a possible unemployed person. Thus education, as part of human resources development, has taken one of the lead aspects of gender equality (GE) achievement.

The process of HE structure change can be followed through human resource diversification [1]. The process of women education has improved from secondary education level to higher as obtaining Master's Degree or $\mathrm{PhD}$. The change of women communication with government and society can be observed as well. In particular, the change in their attitude towards skills usage. However, it differs from country to country $[2,3,4,5]$.

Women empowerment (WE) in higher education (HE) being one of the priorities of GE has had a great impact on the economic and political activity of women [6]. Thus, there appears a change in the contribution of women in society as well as their attitude towards education. However, the list of graduate students is still overfull with specialists in the same areas, leaving behind necessary specialties. This increases the lack of specialists in one area with overload in another.

Kazakhstan, as the rest of the world, is undergoing the process of GE in HE by increasing opportunities for women. The aim of this study is to explore women perceptions of higher education opportunities. The object of this study is women who continue their education entering by Master degree or $\mathrm{PhD}$. The subject of this study is women vision of opportunities they can gain if they have higher education or if they see any benefits from entering higher education.

There are many studies, which discuss the importance of education for women. Previous studies of women empowerment through education considered women who continued their career in $\mathrm{HE}$ institutions or access to education in general. The theoretical implication is that current research will try to fill in the gap of women inner reasons for obtaining higher education. There can be identified hidden factors which have influence on women decision to continue whether to their education or not.

The practical implication is that the results of this study can be used in the development of a country's policy in the delivery of GE. In particular, this is more relevant in countries where higher education is accessible for women at all levels, starting from secondary education to post-doctorate level. Therefore, the government needs to understand the drivers of women's desire for education in order to create conditions for further implementation of newly obtained skills, knowledge and competencies.

\section{Literature review}

In the past women had a very short list of rights. Therefore, women of previous years were taken as dependent women and not only financially. They had no rights to vote, to have education, to run own business or own property. In view of such conditions, education has been regarded as a mechanism for women empowerment achievement [2]

With the rise of such topics as GE, SD the studies devoted to education covered various fields. These studies include not only current situation worldwide, but describe the history of women participation in education region-wise as well $[3,4,5]$. This allows following women communication change, in particular in terms of HE. This is observed through the identification of key factors that have impact on women rights for education obtaining.

First, higher education stands out as one of the drivers of women empowerment as well as GE [6] and SD achievement. The process of HE structure change, its content are the subject of many studies. In some studies, the change in the access of HE started from women education secularization. This is mostly related to the regions where education is closely connected with religion. Education secularization act has led to women realization of their rights and importance of their potential development [5]. Some studies discuss a positive correlation of $\mathrm{HE}$ access for women with economy development as labor force diversification, development of women-run businesses and creation of new work places[7,8]. Some talk about a positive influence of women obtaining $\mathrm{HE}$ on their political activity. Interestingly, both the structure and the content of politics, just like education was noticed as having a positive impact [9]. In various studies, there are identified core challenges for women in HE. Among them, there are family-related issues, glass ceiling, and cultural peculiarities [8]. Cultural standards play a crucial role in many societies. This also includes family responsibilities. Still, family burden takes up one of the leading factors which barrier women from achieving high goals in their carrier promotion.

For instance, in the study of Renju (2012), there were identified three important issues for women to empower in HE: cultural mismatch, education availability at all levels, and gender 
inequality in HE structure. The author offers ways of improving current state of actions for women in terms of leadership [10]. S. Felgendreher and $\AA$. Löfgren (2018) discuss the mismatch of gradual change of the education system for introduction of education for sustainable development (SD) [3]. They have supported the study of Krupka and Weber (2013) that social opinion or believes have impact on the opinion and actions of individuals [11].

Secondly, studies are tightly connected with women's rights. There has been developed another mainstream of studies devoted to the positive correlation of development of various movements, cultural and social organizations, not only feminist, with women desire to study. This as well confirms the impact of social opinion on individuals decision making.[12,13].

Thirdly, all above-mentioned directions study education impact on women empowerment and discuss the issues related to GE in the structure of HE. However, very few talk about the growing number of women in HE among staff and students along with the increase of unemployed women among the educated population [14].

Barsoum G. (2018) stressed that women have different scenarios of promotion in HE. This largely depends on the context of their environment. Among them are family-related issues and personal experience. N.McKee et al (2014) identified key factors, which affect women enrollment to universities, defining them as social behavior [15]. G.Noreen and H.Khalid(2012) researched not only factors which have influence on women in HE, but barriers in HE and career as well [16]

In the study of Valeen et al. (2017) they are investigating the impact of various factors on women empowerment in HE. Particularly there are discussed career opportunities and social support. Advancing in career is described as a vision in the minds of women leaders in education. However, there is no plan or developed mechanism, for promotion. At the same time, social support factor was not identified as having a positive effect. Especially in the case of career promotion awareness. According to the results of their study, social support has a negative impact at the individual level. For instance, social support or pressure could direct a person in a quite different direction as a change of a job etc. [17].

Despite the wide variety of issues related to women empowerment, their promotion through HE has been studied in various ways. Yet there is still lack of information. In addition, authors are struggling in associating women-specific barriers in HE. Previous works investigated the outcomes of GE in HE for women. They are more related to the achievement of GE or SD goals. Current study will try to explore the opposite way.

Throughout the literature review, we have identified some facts, which have impact on women empowerment in career and HE. The following factors are regarded as main factors: environmental context and background, social support, career awareness. However, there is little information about the opinion of women. Their vision of HE importance still needs to be understood. It still needs to be discussed from the perspective of possible carrier opportunities not only among those who have not decided to continue education. It is important to know the motives, desire of women to promote in HE structure as qualification receivers and the members of the academic staff. Even though women obtain high degrees of education, it is important to know what barriers women see for themselves. It is important to learn more about women vision of their future and carrier by obtaining HE.

Based on the literature review, there is still lack of factors, which affect women's choice to continue their education. This study will be provided through qualitative research. Thus, the aim of this study is to explore the following question: What is women vision of higher education opportunities in terms of self-improvement? What outcomes do women see for themselves in obtaining HE?

\section{Theoretical framework and methodology}

The theoretical framework of this study is based on theories of social and behavior communication change and women empowerment. The design of the study is developed based on three works, related to the mentioned theories. First, the study of N.McKee et al.(2014), which is based on the four key social behavior facts. They are as follows: Importance of the context of the information, the impact of cultural standards and networks, well-being and health are of a high priority, and the impact of problems on the behavior.

Secondly, according to the study of Barsoum G. (2018) there have been provided interviews among women who have Master Degree, $\mathrm{PhD}$ or studying at the moment.

Thirdly, a semi-structured interview was developed. The interview was conducted among 11 women who are current $\mathrm{PhD}$ students (7) and graduated Master Degree (4). The interview was divided into 2 parts. The first part included 4 descriptive questions related to the marital status of respondents, their educational background, and age. The second part of the interview was based on the study of G.Noreen and H.Khalid (2012) and consisted of 7 groups of question. G.Noreen and H.Khalid(2012) in their study they were exploring 
the importance of HE, barriers in carrier promotion and women potential. The interview was provided among women occupying top positions at higher educational institutions [16]. This study is directed at exploring the motives, the desire of women to continue their education and to learn more about their vision of HE opportunities. Therefore the respondents of this study were current $\mathrm{PhD}$ students. Accordingly, the questions of the study were adapted, one group of questions was added to complete the 4 key factor framework of N.McKee et al.(2014).

The provision of interviews. All respondents were informed of the interview anonymity. They also had the choice of giving broad or short answers. They also could omit questions if they experienced discomfort answering them. Conditioned to present realities with COVID-19 the interviews were provided in 2 ways:

1. Women were interviewed over telephone. During the interview, there were made notes. The interview was not recorded
2. Women received the list of questions and provided audio notes of their answers.

For the interview analysis, Dedoose software was used. All the interview transcripts were noted, downloaded and specific codes were developed. During the analysis there were developed 48 codes including sub-codes in some cases. The Interviews for $\mathrm{PhD}$ respondents differed from $\mathrm{MA}$ respondents in the volume. $\mathrm{PhD}$ gave broader answers. Their answers included the evaluation of social conditions countrywide and commented on more widespread situations in terms of women empowerment. MA respondents were mostly of a personal experience and the answers were not as broad as PhD. Therefore we provided a separate analysis of $\mathrm{PhD}$ respondents.

All answers were analyzed and divided into 7 groups of answers. Every group analysis included all issues and factors mentioned by the respondents. Then, the final analysis is given according to the 4 key factors of social behavior communication change. There is also given a short analysis of gender balance in Higher Education structure:

Table 1 - Used statistics

\begin{tabular}{|l|l|l|}
\hline No & \multicolumn{1}{|c|}{ Data statistics } & \multicolumn{1}{c|}{ Data collected/developed } \\
\hline 1 & Gross enrolment rate index & $\begin{array}{l}\text { Agency for strategic planning and reforms of the Republic of } \\
\text { Kazakhstan }\end{array}$ \\
\hline 2 & $\begin{array}{l}\text { Gross enrolment rate index including } \\
\text { Master degree, PhD, Residency }\end{array}$ & Calculated according the UNECE toolkit by Jessica Gardner, 2016 \\
\hline 3 & The share of academic staff & $\begin{array}{l}\text { Agency for strategic planning and reforms of the Republic of } \\
\text { Kazakhstan }\end{array}$ \\
\hline
\end{tabular}

\section{Results and discussion}

The number of students who entered HE for the last 10 years has increased for both sexes. The statistics given in the figure 1 include all levels of higher educations. As it is seen from the data, more women have been applying for HE rather than men. Despite the increase for both sexes, women remained greater in the number of enrolled students for about $10 \%$ in 2000 making up $41,29 \%$. By the end of the period, the gap between male and female students increased by almost $30 \%$ and made up $61,05 \%$ and 73,18 respectively.

The data in the table 1 describes gross enrolment rate among men and women for 3 years (2017-2019) among students of Master Degree, $\mathrm{PhD}$ and Residency. According to the statistics, it is seen that women and men have almost achieved Gender Parity in these three directions of HE. Nevertheless, women make up the majority of students in the given categories with $1 \%$ difference in favor of women. The increasing number of women applying for $\mathrm{HE}$ can be also explained as an increasing number of unemployed women. Out of all unemployed population, who have professional qualifications and formal education women make up almost 56\%. Whereas women with higher education (MD, PhD, Residency) make up 34,3\% of all unemployed women, which is $3 \%$ more than men. It can be predicted that women are pushed to enter $\mathrm{HE}$ for the above-mentioned categories, as they face difficulties in finding a job.

In terms of academic staff, women have improved their positions in terms of education suppliers. Though gender policy has been undergoing transformations in order to bring it closer to its foreign policy, there are blind spots in Kazakhstan, which are worth discussing. After the adoption of the Bolonga declaration, more women got involved in education. Specifically among higher ranks $(\mathrm{PhD}$, Full Professor, Doctor of Science, and Candidate of Science). 


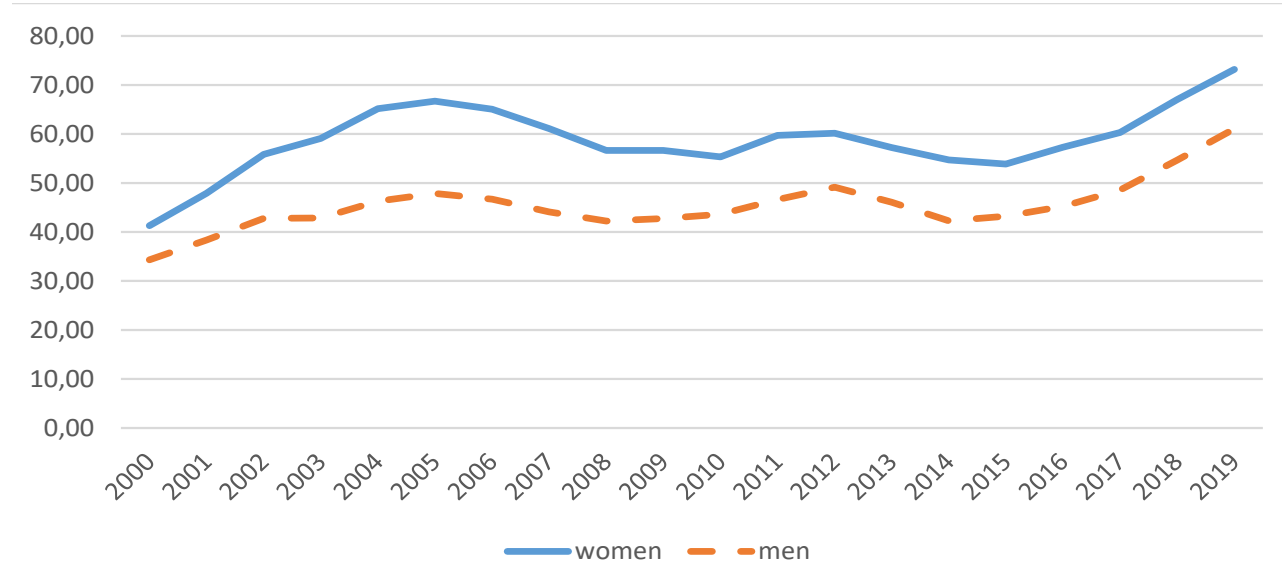

Figure 1 - Gross enrolment rate (\%) for higher education, by sex, 2000-2019

Table 2 - Gross enrolment index, by sex, 2017-2019

\begin{tabular}{|c|c|c|c|c|c|c|}
\hline \multirow[t]{2}{*}{ Year } & \multicolumn{2}{|c|}{$\begin{array}{l}\text { HE students (Master Degree, PhD, } \\
\text { Residency) thousands }\end{array}$} & \multicolumn{2}{|c|}{$\begin{array}{l}\text { Eligible population } \\
\text { (21-49 y.o.) thousands }\end{array}$} & \multicolumn{2}{|c|}{$\begin{array}{l}\text { Gross enrollment } \\
\text { index, \% }\end{array}$} \\
\hline & Women & Men & Women & Men & Women & Men \\
\hline 2017 & 263129 & 213945 & 3882025 & 3761379 & $7 \%$ & $6 \%$ \\
\hline 2018 & 292200 & 250200 & 3885707 & 3772591 & $8 \%$ & $7 \%$ \\
\hline 2019 & 321600 & 282700 & 3874306 & 3770107 & $8 \%$ & $7 \%$ \\
\hline
\end{tabular}

Though the difference between male and female academic staff was about $10 \%$, the number of men in these academic ranks and positions decreased. Women at the end of 2017-2018 academic year made up 54\%. The growth of women's interest in obtaining higher education $(\mathrm{MD}, \mathrm{PhD})$ gives women more opportunities for a job promotion. Thus since 2008 women participation among academic staff in HE has increased for about 9\%. Interestingly, men participation on the contrary decreased steadily throughout the period. Again, it must be noted, this is not the case of substitution. Current statistics, as shown in the figure 2, is built on the basis of four categories: Doctor of Science, Full Professor, Candidate of science, Assistant Professor.

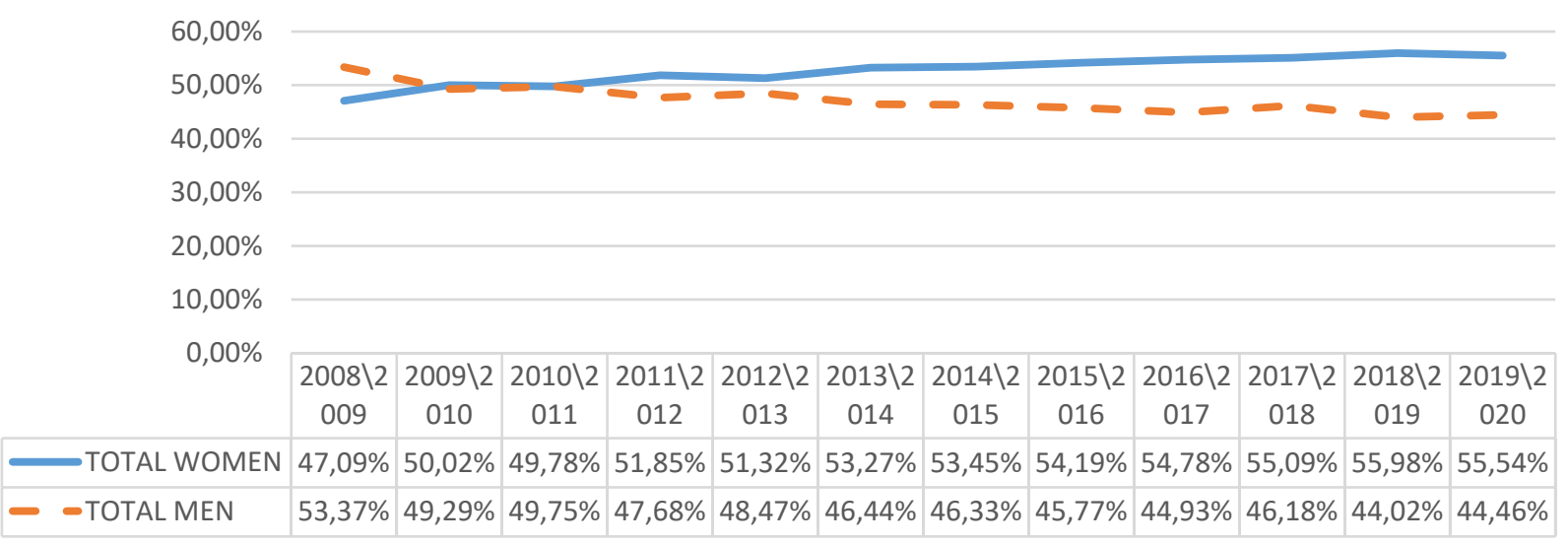

Figure 2 - The share of Women and Men teaching staff of higher educational institutions (\%), in Kazakhstan 
Assuming that the first waves of Bolonga era students graduated with Bachelor degrees in 2007/2008 and 2008/2009 academic years, they started entering $\mathrm{PhD}$ in the following years. The number of Candidates of Science fluctuated between just above and below $31 \%$ until 2011/2012 academic year. Then, the share of women recovered slightly and reached a peak of about $34 \%$ in 2018/2019 and decreased insignificantly in the following year. Relatively, the same trend is observed for Doctors of Science and a Full Professor. It is quite often that, for instance, university professors work parttime due to a number of reasons: family-related, low income, etc. The system itself has created the conditions for women in such a way that they have to work in several universities part-time to earn for living. In cases of a part-time job, they are more often considered as non-staff. On the contrary, the picture for the position of an Assistant Professor, the share of women decreased slightly from $14,37 \%$ in $2008 / 2009$ to $13,19 \%$ in $2018 / 2019$, but in the last academic year, it increased for $2,44 \%$. All in all if compared to the figures at the beginning of the period the difference is $1,26 \%$. Thus, overall difference is insignificant as well.

Current situation in HE structure has improved. We may predict that the goals of the government in provision of gender equality in obtaining HE is achieved. Still, there must be applied different approaches in solving women participation in HE depending on other results aimed. Whether it is gender parity in the number of students, gender equality in the structure of $\mathrm{HE}$ or women empowerment, and increase of their economic activity.

\section{Interview analysis}

According to the interviews provided, family wellbeing is of a high priority for women. In some cases, it is accepted as a burden, in others as a life mission. Despite a clear pattern that women education increases income, does not have impact on the attitude and behavior of women and their families towards women obtaining of HE. Therefore, we have identified the following factors: Social support/pressure, Career awareness, Cultural standards, Context

Throughout the analysis of the interviews there have been developed 48 codes. In the figure 3 , there is presented information with a division of answers between women who are doing $\mathrm{PhD}$ and who have MA Degree. Following parent factors have greater impact or higher importance: cultural standards, decision to continue education, $\mathrm{HE}+$ career opportunities, no obstacles, social impact and personal development.
Of all sub-factors for cultural standards, family and home routine are of greater impact on women career promotion or decision to continue education. Whereas home routine has a negative impact as it identifies women position in the society and family hierarchy from childhood. Family stands out as a great influencer in terms of women decision to continue education. It has both positive and negative effect. As for negative effect, it is assigned to such cultural and national traditions of early marriage and women duties, which are related to home routine. Majority of the respondents, including all MA respondents decided to continue their education on their own. Half of the $\mathrm{PhD}$ respondents made decisions on their own, but, interestingly, they do not deny the influence of their family members as well. This gives us the understanding, that $\mathrm{PhD}$ degree is mostly dependent on social support or pressure. Only one respondent said of the negative influence of social support from her colleagues. This was due to gender stereotypes related to women mission as to get married and have children.

Allrespondentsfind notobstaclesorrestrictions to continue HE, unlike job opportunities. When applying for work some of them have faced gender stereotypes issues. Two of them were not hired for work due to employer predictions of possible soon marriage based on their age. Consequently, women would go for long-lasting maternity leave. As the employers predicted, women tend to have two children with one or two years gap. Therefore, the maternity leave would be prolonged. Based on the cultural standards, women have to take care of their children, family and their productivity would be less than expected. Interestingly, the fact that women assured the employers of husband support had no effect. Which could be accepted as low credit for husband support. The rest experience no difficulties in applying for work, they faced not gender pay gap. Moreover, all conditions and requirements as well as benefits were equally accessible for women and men.

Mostly, MA respondents emphasized that selfdevelopment as important for women, show the relevance to HE. Personal development is not only regarded as positive for women themselves, but for society as well. Educated women are more society oriented as there in full access to information, women are aware of job opportunities, social issues. The more women have HE, the better the conditions and development of social policy will be in the country. If a woman is not interested to continue education through HE or training, courses (self-development), then she is not interested in the environment. 


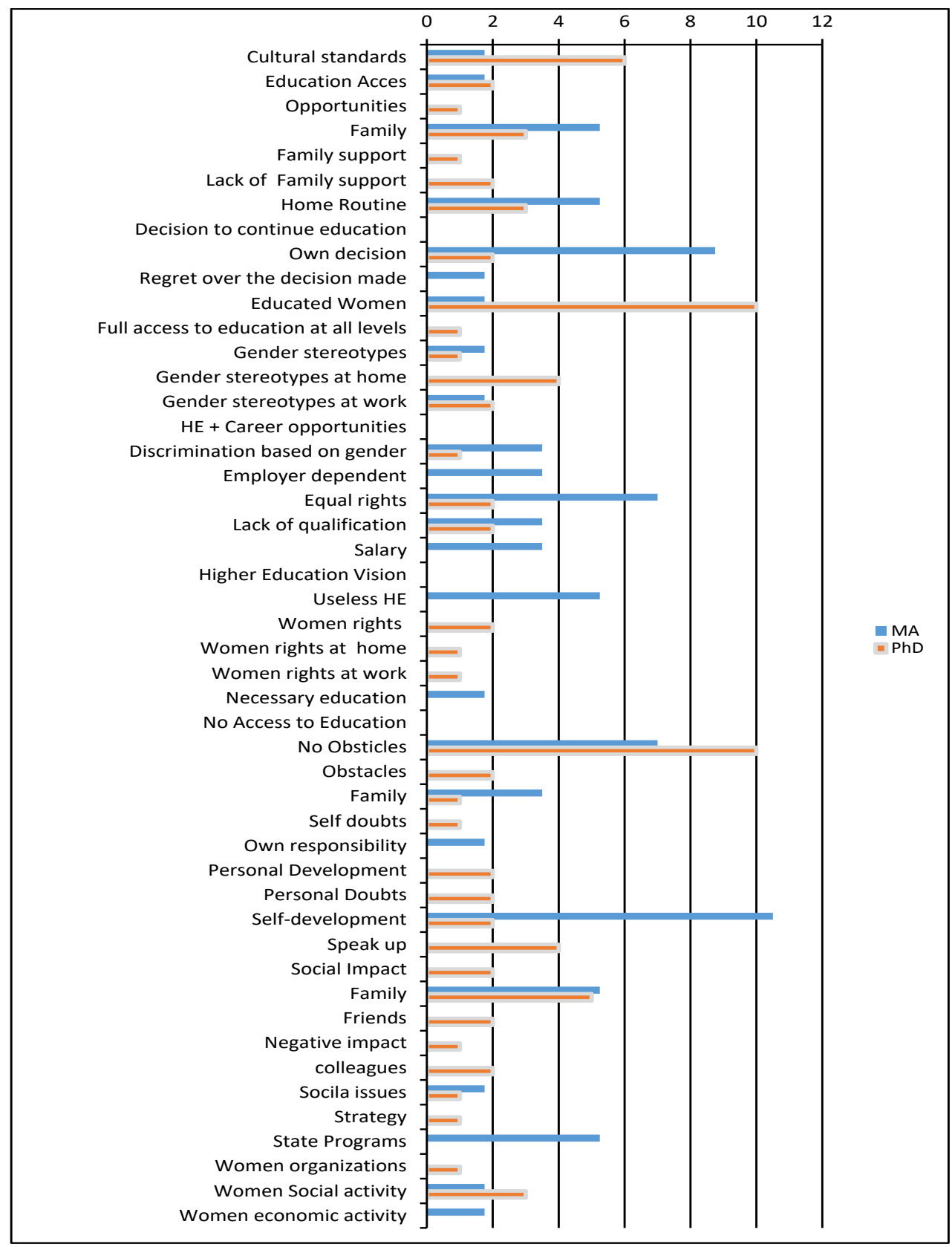

Figure 3 -Women decision to continue HE factors, sub-factors

As for the strategies for women empowerment, realization of their potential, some respondents found it difficult to share any ideas. Almost half of them underlined development of state educational programs designed for women as a good way to improve women career and education opportunities. Three of the respondents advised using foreign experience in terms of educational programs with further advancement in career. One of the respondents mentioned that western practices could be used in bringing up children as well. This was advised to reduce cultural impact, i.e. early marriages, low access to secondary and higher education. Development of women organizations or feministic is also regarded as one of the methods to support and promote women rights. This was mostly advised as a helpful tool for women themselves, rather than a part of a state policy and state goals. $\mathrm{PhD}$ respondents mentioned that women need to be determined in their actions, must be less amenable to society persuasions. This can develop confidence in them.

As for the vision of HE opportunities for women, $\mathrm{PhD}$ respondents stressed the relation of women rights development through $\mathrm{HE}$ obtaining. For MA respondents it is different. One of them 
disagreed that women can improve their rights through education. The respondent is sure that women with higher education have the same rights and opportunities as women without HE ( it is probably predicted by the respondent $\mathrm{MA}$ and $\mathrm{PhD}$ ). The other two spoke about the uselessness of HE, as it has never been requested by employers. One of the respondents emphasized regret of the time spent on HE, as it does not give any dominance over those who do not have HE.

To sum up, women mostly see no opportunities for further skills application. They face difficulties in finding a job due to applying their skills, as they are not aware of opportunities HE can give. They mostly assign themselves to social duties. The same as at home, in the streets women are interested in improving social policy, worried about the future generation. Despite the opinion of respondents of women mission, that women are not only mothers or wives, they keep assigning the same duties for women in the society. For example, an educated woman brings up an educated generation, which favors the entire country. According to the opinion of one MArespondent, society still accepts a woman as a mother or a wife in all aspects of life. To help women to develop skills and realize their potential, society needs to see the potential. Current state of actions shows women are dependent on social impact, which can be both negative and positive. Even though it is originally social support.

\section{Results of PhD Interview respondents The context of women decision to continue education.}

Throughout all interviews, there were identified some factors that had influenced women decision-making. In 4 cases the decision was made based on the recommendations of family members, colleagues, and friends. In 3 cases the decision was made under the influence of social standards. Whereas in one situation the respondent believed in the beginning, that it was her own choice. Some of them mentioned that it would have been much easier to combine family with the support of family members, especially the support of a husband. In one case there was underlined a negative opinion of friends to continue education. However, the decision of the respondent was based on the examples of their family members, who are in HE as well.

\section{Women vision of higher education contribution.}

Some respondents considered that secondary education stands out as a necessity or a tool for women further achievement of their rights and expansion of their possibilities and worldview. Educated women, who read a lot, self-educate and strive for new knowledge, have much more opportunities. It gives them such qualities as selfconfidence, possibility to make own decisions. Educated women have a positive impact of bringing up children. Otherwise finding a job becomes very complicated.

Education gives more privileges in terms of job finding as it provides possibilities to find a good job, receive income, higher. Status, intelligent work. Thus, women are not limited to the job, which can damage their health. Therefore, the importance of finding a job is conditioned to the field of activity, which gives rise to the priority of education, for compliance with the labor market.

Other positive outcomes, which are provided by $\mathrm{HE}$ are integration and adaptation in society, self-defense, empowerment, good employment and again good pay or pay increase. One respondent sees no impact of $\mathrm{HE}$ on women rights at work or at home.

Among the barriers for women in HE two of them mentioned no barriers except financial issues, which did not allow them to study in the desired institutions. For two respondents education stands out as a source of income.

Gender-related issues, cultural differences, and family issues are closely related to each other.

First of all, gender stereotypes, especially in rural regions or towns in Kazakhstan do not predict education privileges for women. Moreover, women are given a role of a mother who has to look after her offspring. Women are also described as having special duties of looking after in-laws and obeying the opinion of family members.

Gender preferences at work limit women promotion as employers make decisions in favor of men for top positions. Describing women as highly dependent on their family issues. Nevertheless, even being single draws other issues. For instance, an employer can predict a possible future marriage followed by soon maternity leave. This would cause other difficulties for a company, as finding another specialist.

Another side factor, mentioned by one respondent is poor social security or support from the government. In some cases, women are pushed to stay at home after they have children, as it requires more time and finances.

All respondents did not find any barriers in obtaining HE in Kazakhstan.

\section{Obstacles to career growth and education opportunities.}

Family-related conditions have the same effect with slight differences in terms of career promotion. For instance, maternity leave prolongs promotion. Marital status, housework, and in-laws take too much time. Consequently, lack of time has become another obstacle. Whereas house works 
prevent women potential full development. Again, possible maternity leave is predicted a possible discomfort for an employer.

Gender stereotypes in cultural customs or standards, in particular, early marriage is mentioned almost by all respondents as having a negative effect.

Three respondents recommended being able to stand for their opinion as there is sometimes lack of subordination in the workplace. Women have to learn new skills to expand the possibilities for promotion, which might be due to the lack of practical education. Nepotism in the answer of one respondent was described as a frequent case in Kazakhstan.

Again, all participants supported that there are no obstacles for women in having education. Moreover, in education, women and men rights are equal. At the same time for some, there were no extra opportunities.

Limitations of difficulties in education were due to lack of husband support, lack of time, laziness, lack of knowledge of the English language. In particular, one respondent supported that it is difficult to balance between family, work, and education.

In terms of work, one respondent stated about equal promotion at work in the private sector, as well as lack of gender pay gap.

\section{Strategies for women potential development}

Most of the recommendations were related to personal qualities development. They are discipline, ambitions, self-confidence, broad view, self-decision making, not be exposed to someone else's opinion, be able to defend own opinion, not giving up and try new horizons. Women should realize their potential. They should not be prioritizing their marriage or family issues over their education, the possibility to realize their potential.

One of the participants recommended adopting masculine traits, immediately look for a job, develop social capital to increase labor activity, etc.

\section{Social transformation through education}

In general, there are no limits for women in HE. The more there are educated women, the more there are social transformations. There will be a way for development of public organizations for the promotion of women rights. A literate woman can raise better generation; accordingly, a better social development could be achieved. In general, there are no obstacles in obtaining HE for women in Kazakhstan. Although it is necessary to solve problems at the regional level or rural areas.
Another way to achieve social transformation is support. First of all, women support each other. Thus female solidarity breeds social transformation. Then government support, that is social work and support of women, organization of specially designed courses for women with the participation of a psychologist.

\section{Women progress restrictions.}

Set of things as family, society, personal limitations have a great impact of women progress. The family impact is noticed in early childhood. When parents build limits in the mid of children as to gender differences what is allowed and what is not. This kills women potential from childhood. Social pressure included gender stereotypes, cultural standards/ traditions, patriarchal society. Another reason is lack of awareness, low level of awareness. Lack of time, which is spent on children and housework. However, with good time management, it could be solved.

\section{Key factors of social behavior communication change Analysis \\ Importance of the context of the information}

In most cases, women are dependent on the social environment. It is clearly followed throughout all answers. First, decisions for HE are usually recommended or taken as a necessary or natural step in life. Second, women even though women understand the limits built by cultural standards, cultural standards are one of the key factors which have a negative impact almost in all given answers.

\section{The impact of cultural standards and networks}

Cultural standards, traditions build up the greatest wall for women to develop own potential. Eventhough there are almost no barriers for women to succeed in education and with education, cultural habits in terms of early marriage, social stereotypes at workplace play a big role in women empowerment.

\section{Impact of problems on the behavior}

Family issues are the situations, which however have impact on the lives of women. Some women take it as a natural sequence of actions, some try to change the situation as they receive support of their families. None of the respondents have mentioned possible opportunities for women to advance in HE. We may predict they are lack of information on opportunities for them in HE.

\section{Well-being and health}

\section{Conclusion}

This study tried to find answers to the following questions: What is women's vision of higher education opportunities in terms of self- 
improvement? What outcomes do women see for themselves in obtaining HE?

Obtaining HE gives women independency and equal treatment in workplace and society. Overall women see the perspectives of obtaining $\mathrm{HE}$ as a tool for achieving GE.

Current preliminary study has given a clear understanding that cultural standards, which include stereotypes development, family habits and networks behavior, have a great impact on women empowerment. Even if the government improves the structure of higher education, there is still a great gap in the provision of gender equality policy in the rest fields of the economy in Kazakhstan.

In order to promote GE in social institutions government should support the development of women organizations, provide introduction of policies in support of women rights. This will help to reduce the impact of social support/pressure on women decision whether to continue education or not.

Government should provide social security and support to society, which would favor women. For instance, opening of more kindergartens with reasonable prices. Under the condition of current context, that women have to jungle between family routine and their work, the government could have developed reforms in the working hours of women. The reforms could also touch upon the environment of women (as the number of children, the location a kindergarten, if there are disabled people in the family etc.). The age group for majority of the respondents was between 27-36 y.o. Two of the respondents are single and do not have children. According to the study of R.Blumberg (2001), we can predict, women as they have children are more concerned about their children's safety [18]. In her study, she argues that women spend most of the income on their children's well-being ( as health, education etc.). As $\mathrm{PhD}$ students receive scholarship, digitalization of education allows remote education women can devote more time to their children

There is lack of information regarding professional opportunities for women. This decreases their interest in advancing in $\mathrm{HE}$ structure. Career awareness brings more positive impact, especially on women's decisions of why $\mathrm{HE}$ is important. Again, none of the respondents mentioned career advancement in international organizations with higher salary, application of their skill in scientific research as paid grants etc. Therefore, it can be predicted that the respondents are not informed in opportunities they can have if obtained $\mathrm{PhD}$

As for MA respondents, they are more career oriented and clearly see their opportunities for their promotion. Therefore, their decisions of MA degree obtaining are own decisions. They are still conditioned to labor market demands. However, these decisions were made on the basis of their own decisions to continue education. Which is different from $\mathrm{PhD}$ respondents. According to their answers, social pressure does not contribute to the development of own understanding of how to develop their skills or realize their potential.

Above mentioned shows government provision of social policy as well as economical support. Therefore, it is important to develop educational programs with further employment or application of their skills in relevant areas. Educational institutions need to develop partnership with private sector. Under the private sector, we mean large companies, international organizations, where it is possible to learn a new method of doing work, foreign practices, and a higher possibility of using knowledge obtained at HE institutions. Government should investigate the situation in rural areas and regions, especially where cultural habits are strong.

\section{Reference}

1. Repina, E.G. (2020). Transformation Of Higher Education: From State Diagnostics To Management Decisions. European Proceedings of Social and Behavioural Sciences. 106, 584-593. doi. org/10.15405/epsbs.2021.04.02.71

2. Sharma, R., Afroz, Z. (2014). Women Empowerment Through Higher Education. International Journal of Interdisciplinary and Multidisciplinary Studies. 1(.5), 18-22.

3. Felgendreher, S., Löfgren, Å. (2018). Higher education for sustainability: can education affect moral perceptions? Environmental Education Research. 24(4), 479-491. doi.org/10.1080/13504622.2017.1307945

4. Barsoum, G. (2018). Women, work and family ': Educated women's employment decisions and social policies in Egypt. Gender, Work and Organization. 26(7), 895-914. 10.1111/gwao.12285

5. Muelsch, E.-C. (2002). The Rise of Professional Women in France. Gender and Public Administration since 1830. Women in French Studies. 10(1), 261-263. doi.org/10.1353/wfs.2002.0000

6. Al-Samarrai, S. (2009). The impact of governance on education inequality: Evidence from Bangladesh . Public Administration and Development. 29(3), 167-179. doi.org/10.1002/pad.529

7. Bishu, S.G., Headley, A. M. (2020). Equal Employment Opportunity: Women Bureaucrats in Male-Dominated Professions. Public Administration Review. 80(6), 1063-1074. doi.org/10.1111/puar.13178

8. Elazhari, E.S. (2021). Cultural impact on social position and women's education in Libya. International Journal of Scientific and Research Publications. 11 (4), 425-427. doi.org/10.29322/ijsrp.11.04.2021.p11257

9. Park, S., Liang, J. (2019). A Comparative Study of Gender Representation and Social Outcomes: 
The Effect of Political and Bureaucratic Representation. Public Administration Review. 00, 1-12. doi.org/ 10.1111/puar.13092

10. Renju, A. (2012). Higher Education and Women Participation in India. Global Journal For Research Analysis. 3(6), 1-4. doi.org/ 10.15373/22778160/ june2014/87

11. Krupka, E.L., R. A. Weber. (2013). Identifying Social Norms Using Coordination Games: Why Does Dictator Game Sharing Vary? Journal of the European Economic Association. 11 (3), 495-524). doi.org/ 10.1080/13504622.2017.1307945

12. Hilbert, M. (2011). Women's Studies International Forum Digital gender divide or technologically empowered women in developing countries? A typical case of lies, damned lies, and statistics. Women is Studies International Forum. 34(6), 479-489. doi.org/ 10.1016/j.wsif.2011.07.001

13. Khan, A., Majeed, S., \& Sayeed, R. (2020). Women Education in India and Economic Development Linkages: A Conceptual Study. International Journal of Engineering and Management Research. 10(03), 77-81. doi.org/ 10.31033/ijemr.10.3.12
14.Assaad, R., Krafft, C., \& Salehi-Isfahani, D. (2018). Does the type of higher education affect labor market outcomes? Evidence from Egypt and Jordan. Higher Education. 75(6), 945-995. doi.org/ 10.1007/ s10734-017-0179-0

15. McKee, N., Becker-Benton, A., \& Bockh, E. (2014). Social and Behavior Change Communication. The Handbook of Development Communication and Social Change. 14, 278-297. doi.org/ 10.1002/9781118505328.ch17

16. Noreen, G., \& Khalid, H. (2012). Gender empowerment through women's higher education: opportunities and possibilities. Journal of Research and Reflections in Education. 6(1), 63-76. doi.org/

17. Ruth van Veelen, Peter J.C. Sleegers, Maaike D. Endedijk. (2017) Professional Learning Among School Leaders in Secondary Education: The Impact of Personal and Work Context Factors. Educational Administration Quarterly. 53(3), 365-408. doi.org/ $10.1177 / 0013161$ X16689126

18.Blumberg, R.L. (2001). We are family : Gender , microenterprise , family work , and wellbeing in Ecuador and the Dominican Republic — with comparative data from Guatemala , Swaziland and Guinea-Bissau. History of the family. 6, 271-299. doi. org/10.1016/S1081-602X(01)00073-2

\title{
Information about the authors
}

\begin{abstract}
Aigerim Yessentay - PhD student, Institute of Economics of the Science Committee of the Ministry of Education and Science of the Republic of Kazakhstan,, e-mail: aigera588@,mail.ru. ORCID ID: https://orcid.org 0000-0003$\underline{3969-4284}$
\end{abstract}

* Gaukhar K. Kenzhegulova - PhD student, NARXOZ University, e-mail:gaukhar.kenzhegulova@gmail.com. ORCID ID: https://orcid.org 0000-0002-1232-4788

Osama M. Rajkhan - PhD, Professor of Bioethics and Holistic Health, American University of Sovereign Nations, Saudi Arabia, e-mail: osamarajkhan@gmail.com

\section{Авторлар туралы мәліметтер}

Есентай Айгерим Есентаевна - докторант, Қазақстан Республикасы Білім және ғылым министрлігі Ғылым комитетінің Экономика институты, Қазақстан, e-mail: aigera588@,mail.ru. ORCID ID: https://orcid.org 0000$\underline{0003-3969-4284}$

* Кенжегулова Гаухар Коблановна - докторант, НАРХОЗ университеті, Қазақстан, e-mail:gaukhar. kenzhegulova@gmail.com. ORCID ID: https://orcid.org 0000-0002-1232-4788

Осама М. Раджхан - PhD докторы, Биоэтика және Біртұтас денсаулық сақтау, профессоры, Американдық Егеменді Ұлттар Университеті, Егеменді Ұлттар Ұйымының, Сауд Арабиясы, e-mail: osamarajkhan@gmail. $\underline{\text { com }}$

\section{Сведения об авторах}

Есентай Айгерим Есентаевна- докторант, Институт экономики Комитета науки Министерства образования и науки Республики Казахстан,e-mail: aigera588@mail.ru. ORCID ID: https://orcid.org 0000-0003-3969-4284

*Кенжегулова Гаухар Коблановна - докторант, университет НАРХO3, e-mail:gaukhar.kenzhegulova@gmail. com. ORCID ID: https://orcid.org 0000-0002-1232-4788

Осама М. Раджхан - PhD, профессор Биоэтики и целостного здоровья, ,Американский университет суверенных Наций, Саудовская Аравия, е-mail: osamarajkhan@gmail.com 